\title{
In vitro somatic embryogenesis and adventitious root initiation have a common origin in eggplant (Solanum melongena L.) ${ }^{1}$
}

\author{
ERIKA TARRÉ ${ }^{2,3}$, CLAUDIA MAGIOLI $^{3}$, MÁRCIA MARGIS-PINHEIRO $^{3}$, GILBERTO $^{4}$ \\ SACHETTO-MARTINS ${ }^{3}$, ELISABETH MANSUR ${ }^{2}$ e LYGIA D.R. SANTIAGO-FERNANDES ${ }^{4,5}$
}

(received: May 7, 2003; accepted: October 23, 2003)

\begin{abstract}
In vitro somatic embryogenesis and adventitious root initiation have a common origin in eggplant (Solanum melongena L.)). Somatic embryogenesis was induced from cotyledon explants of eggplant cultured on MS medium supplemented with $54 \mu \mathrm{M}$ NAA. Anatomical analysis of somatic embryo initiation and development was performed during the first four weeks. Proembryo formation was observed after the second day of culture, directly from perivascular cells or via pro-embryogenic masses derived from indeterminate meristematic masses (IMMs) originated in the vascular tissue. Those IMMs also gave rise to root primordia after 10 days of culture. The origin of embryos is discussed as well as the similarities between somatic embryogenesis and adventitious root formation.
\end{abstract}

Key words - anatomy, development, Solanum melongena, somatic embryogenesis

RESUMO - (Embriogênese somática in vitro e iniciação de raizes adventícias têm uma origem comum em berinjela (Solanum melongena L.)) A embriogênese somática em berinjela foi induzida a partir de explantes cotiledonares cultivados em meio MS suplementado com $54 \mu \mathrm{M}$ de ANA. A análise anatômica do início de formação e desenvolvimento de embriões somáticos foi realizada durante as primeiras quatro semanas. A formação de pré-embriões foi observada após o segundo dia de cultura, diretamente a partir de células perivasculares ou a partir de massas pré-embriogênicas derivadas de massas meristemáticas indeterminadas (IMMs) formadas a partir do tecido vascular. As IMMs também deram origem a primórdios radiculares após 10 dias de cultura. A origem dos embriões é discutida, assim como as similaridades entre a formação de embriões somáticos e raízes adventícias.

Palavras-chave - anatomia, desenvolvimento, Solanum melongena, embriogênese somática

\section{Introduction}

Somatic embryogenesis is an important pathway for the regeneration of plants from cell culture systems and a method commonly used in large scale production of plants and synthetic seeds (Stuart et al. 1987). Somatic and zygotic embryos undergo basically the same stages of development, namely globular, heart-shaped, torpedo and cotyledonary. Both somatic embryogenesis and in vitro cultured zygotic embryos are being employed to address long-standing questions concerning the role of

\footnotetext{
1. Monografia de conclusão do curso de Bacharelado em Ciências Biológicas, Universidade do Estado do Rio de Janeiro

2. Universidade do Estado do Rio de Janeiro, Departamento de Biologia Celular e Genética, Laboratório de Micropropagação e Transformação de Plantas, R. São Francisco Xavier 524, PHLC, sala 505, 20550-013 Rio de Janeiro, RJ, Brasil

3. Universidade Federal do Rio de Janeiro, Departamento de Genética, Laboratório de Genética Molecular Vegetal, Av. Pau-Brasil 211, A2-76 - CCs, 21941-040 Rio de Janeiro, RJ, Brasil.

4. Universidade Federal do Rio de Janeiro, Museu Nacional, Departamento de Botânica, Laboratório de Anatomia Vegetal. Quinta da Boa Vista, São Cristóvão, 22940-040 Rio de Janeiro, RJ, Brasil.

5. Corresponding author: lygia@mn.ufrj.br
}

growth regulators as well as the limits of influence of maternal tissues and endosperm on zygotic embryos (Schmidt et al. 1994). The analysis of somatic embryo development can also significantly contribute to the understanding of early morphogenetic events in plant embryogenesis, such as the establishment of polarity and the differentiation of tissue systems (Zimmerman 1993).

One of the main problems when using somatic embryogenesis as a model system is the lack of information on the early events involved in the embryo induction process (Dodeman et al. 1997). In this context, information concerning the commitment of a particular cell or tissue is desirable for studies on the regulation of gene expression during the earliest developmental events in higher plants.

The site of somatic embryo induction and their developmental pattern are highly variable according to the species and explant type. Histological analysis performed in several plant species showed that somatic embryo development may occur from epidermal (Hutchinson et al. 1996, Newman et al. 1996, Sagare et al. 1995), parenchymatous (Sagare et al. 1995) or vascular cells (Ho \& Vasil 1983, Schwendiman et al. 1988, Buffard-Morel et al. 1992, van Hengel et al. 1998, Guerra \& Handro 1998). 
Eggplant somatic embryogenesis studies using different growth regulators and various explants including leaves (Gleddie et al. 1983, Fillipone \& Lurquin 1989, Rao \& Singh 1991), cotyledons (Saito \& Nishimura 1994), zygotic embryos (Yamada et al. 1967) and hypocotyls (Matsuoka \& Hinata 1979) have been reported. A highly efficient and reproducible embryogenic system using middle sections of cotyledons has recently been developed (Magioli et al. 2001), which can be useful as a model for studying different aspects of plant embryogenesis. In the present work, a histological analysis addressing the origin and development of somatic embryos was performed in order to improve the usefulness of this system for such studies.

\section{Material and methods}

Plant material and culture conditions - Seeds of eggplant (Agroceres F-100 variety) were washed with Tween $200.05 \%$ and surface sterilized with $5 \%(\mathrm{v} / \mathrm{v})$ sodium hypochlorite, for 25 minutes. The seeds were then rinsed three times with sterile distilled water and placed on flasks containinig culture medium (10 seeds per flask). The basal medium used consisted of salts and vitamins of MS (Murashige \& Skoog 1962) supplemented with $3 \%$ sucrose and $0.7 \%$ agar (w/v). Medium $\mathrm{pH}$ was adjusted to 5.8 before agar addition and autoclaving at $121^{\circ} \mathrm{C}$ for $15 \mathrm{~min}$.

Cotyledon explants $\left(1 \mathrm{~cm}^{2}\right)$ excised from 21-day-old plants germinated as described were inoculated with the abaxial side down on MS medium supplemented with $54 \mu \mathrm{M}$ $\alpha$-naphtaleneacetic acid (NAA). Each flask contained five explants. After 30 days of culture, somatic embryos at the cotyledonary stage were transferred to MS medium devoid of growth regulators (MS0) and gelled with 1\% Phytagel (Magioli et al.2001). Plant material was maintained in a growth chamber at $28 \pm 2{ }^{\circ} \mathrm{C}$ with a $16 \mathrm{~h}$ photoperiod provided by cool-white fluorescent lamps (General Electric) and a photon fluency of $36 \mu \mathrm{mol} \cdot \mathrm{m}^{-2} . \mathrm{s}^{-1}$.

Anatomical analysis - Ten explant samples were fixed daily during the first 10 days and at 5 days intervals up to 30 days of culture. Samples were fixed in $2.5 \%$ glutaraldehyde and $4 \%$ para-formaldehyde in $50 \mathrm{mM}$ sodium phosphate buffer, $\mathrm{pH}$ 7.2 and stored at $4{ }^{\circ} \mathrm{C}$. After dehydration in a graded ethanol series $(30 \%, 50 \%, 70 \%$ and $90 \%)$, the specimens were embedded in Histocryl resin (London Resin Co.) and serially sectioned with glass knives on a Sorvall ultramicrotome. Sections ( $1 \mu \mathrm{m}$ thick) were stained with $0.1 \%$ Toluidine Blue (Gahan 1984). Representative sections were photographed with an Orthomat Leitz photomicroscope. Starch was identified using $0.5 \%$ iodine in $5 \%$ potassium iodide (Gahan 1984).

\section{Results}

Cotyledon explants showed the first signs of cell proliferation within the first two days of culture when several proembryos arose directly from parenchymatic perivascular cells surrounded by the mesophyll parenchyma (figures 1-4). This process was observed up to eight days of culture (figure 5). After three days of culture, an intense process of cell proliferation along the vascular bundle could be seen separating the tracheary elements and increasing bundle thickness. Those cells give rise to clusters which were named indeterminate meristematic masses (IMMs) (figure 6). IMMs further generated pro-embryogenic masses (PEM), which produced numerous embryos that became gradually spread through the cotyledonar parenchyma (figure 7). During this process, cells of the adjacent parenchyma with small starch grains and large vacuoles showed alterations indicating cell degradation (figure 6), including retraction of the protoplast, reduction of the vacuole volume and cytoplasm fragmentation (data not shown).

Sections taken after four days of culture exhibited many endogenous PEMs still embedded in the cotyledon tissue. Those masses were composed of thin walled dividing cells organized in three distinct regions (figure 8): a) vacuolated cells, nearest to the vascular bundle with cells bearing several vacuoles and dense cytoplasm; b) eumeristematic cells, with dense cytoplasm and absence of vacuoles; c) differentiated cells, with a less dense cytoplasm filled with starch grains and with some degree of vacuolization. Somatic embryos emerged from the distal differentiated layer while new PEMs arose continuously along the vascular tissue.

After the first week, some of the peripheric cells of the IMMs began to produce root-like structures, initially similar to the young PEMs, but soon showing the characteristic root organization pattern. The number of new roots became increasingly higher, whereas PEM formation was reduced. Numerous root primordia were densely disposed along the bundles after ten days. Roots are observed in calluses with 30 days of culture. New tracheary elements were continuously formed increasing the bundle volume (figure 9). At the same time, proembryos continue to arose directly from parenchymatic perivascular cells (figure 5).

Globular and early heart-shaped embryos were clearly visible among the dissociated mesophyll parenchyma after four days of culture (figures 10-13). 

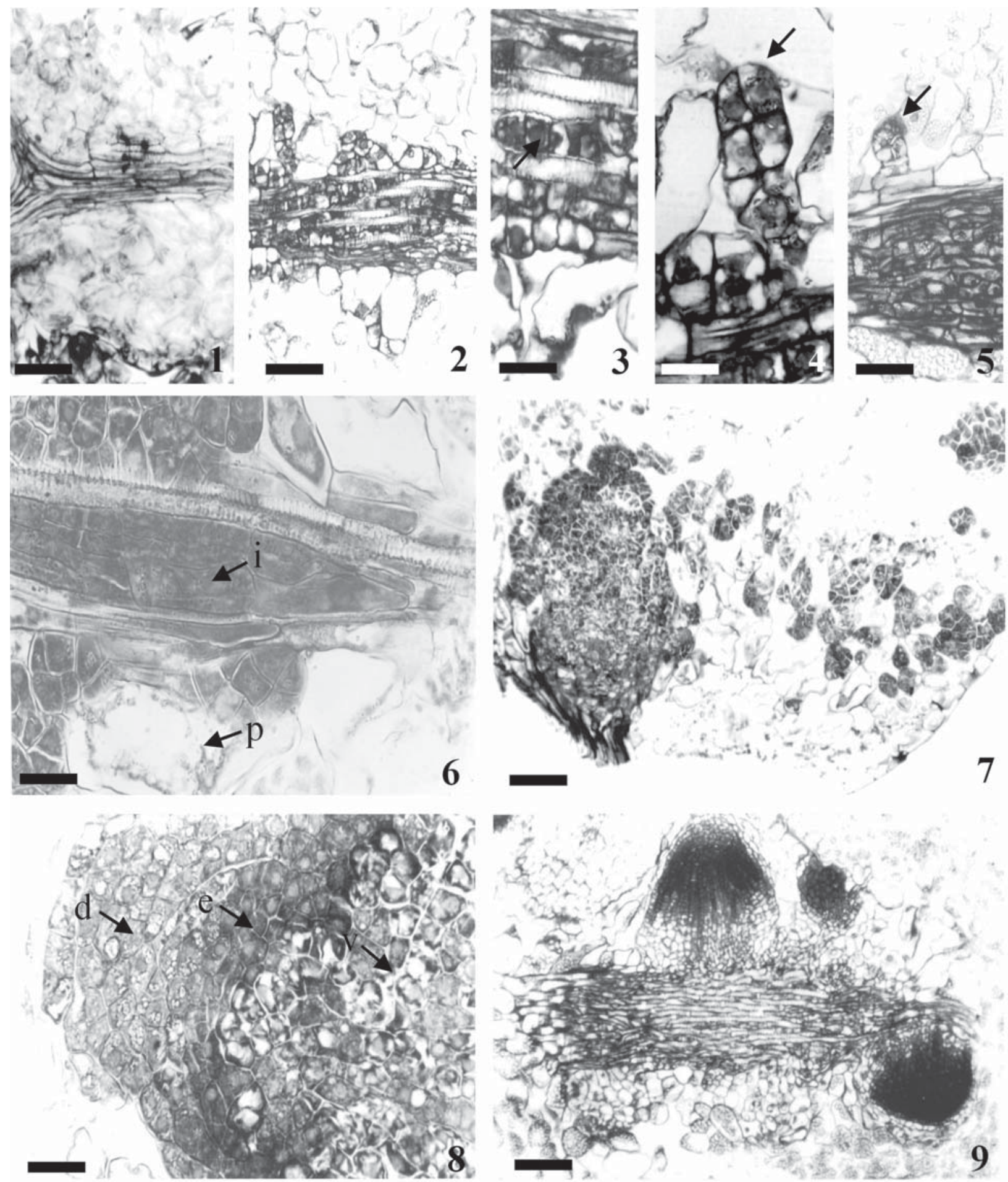

Figures 1-9. Differentiation of somatic embryos from cotyledon explants of eggplant. 1. Section of cotyledon explant excised from 21-day-old plantlet at the time of culture showing the vascular bundles. 2. Cross section of cotyledon explant after two days in culture. 3. Detail of cell proliferation from the vascular bundle after two days in culture. 4 . Detail of proembryo directly originated from the vascular bundle after two days of culture. 5. Proembryo directly originated from the vascular bundle after eight days in culture. 6. IMM proliferation between two tracheary elements after three days of culture $(i=I M M ; p=$ parenchymatic cells). 7. PEM forming numerous embryos after three days in culture. 8. Regions of PEM after four days in culture (d= differentiating cells; $\mathrm{e}=$ eumeristematic cells; $\mathrm{v}=$ vacuolated cells). 9. Increased vascular bundles showing new tracheary elements and root primordia along the bundle after 10 days of culture. Bars $=82 \mu \mathrm{m}(1) ; 139 \mu \mathrm{m}(2,5) ; 11.25 \mu \mathrm{m}(3,4,18) ; 8 \mu \mathrm{m}$ (6); $43 \mu \mathrm{m}$ (7); $94.73 \mu \mathrm{m}$ (9). 
Suspensor-like structures were observed in some of these embryos (figures 10,11) consisting of several arrays of cells, which corresponded to almost half of the embryo length. Late heart-shaped embryos showed many starch grains in the protoderm, ground tissue and especially in the region next to the procambium (figure 13).

Structures similar to torpedo stage embryos but lacking the root pole and thus resembling shoots were also observed (figure 14). The most developed PEMs progressively formed friable, semi-translucent calluses along the explant. Within 30 days hundreds of embryos were visible to the naked eye (figure 15). Ninety two percent of these embryos were converted to whole plants, originating phenotypically normal plants (Magioli et al. 2001).
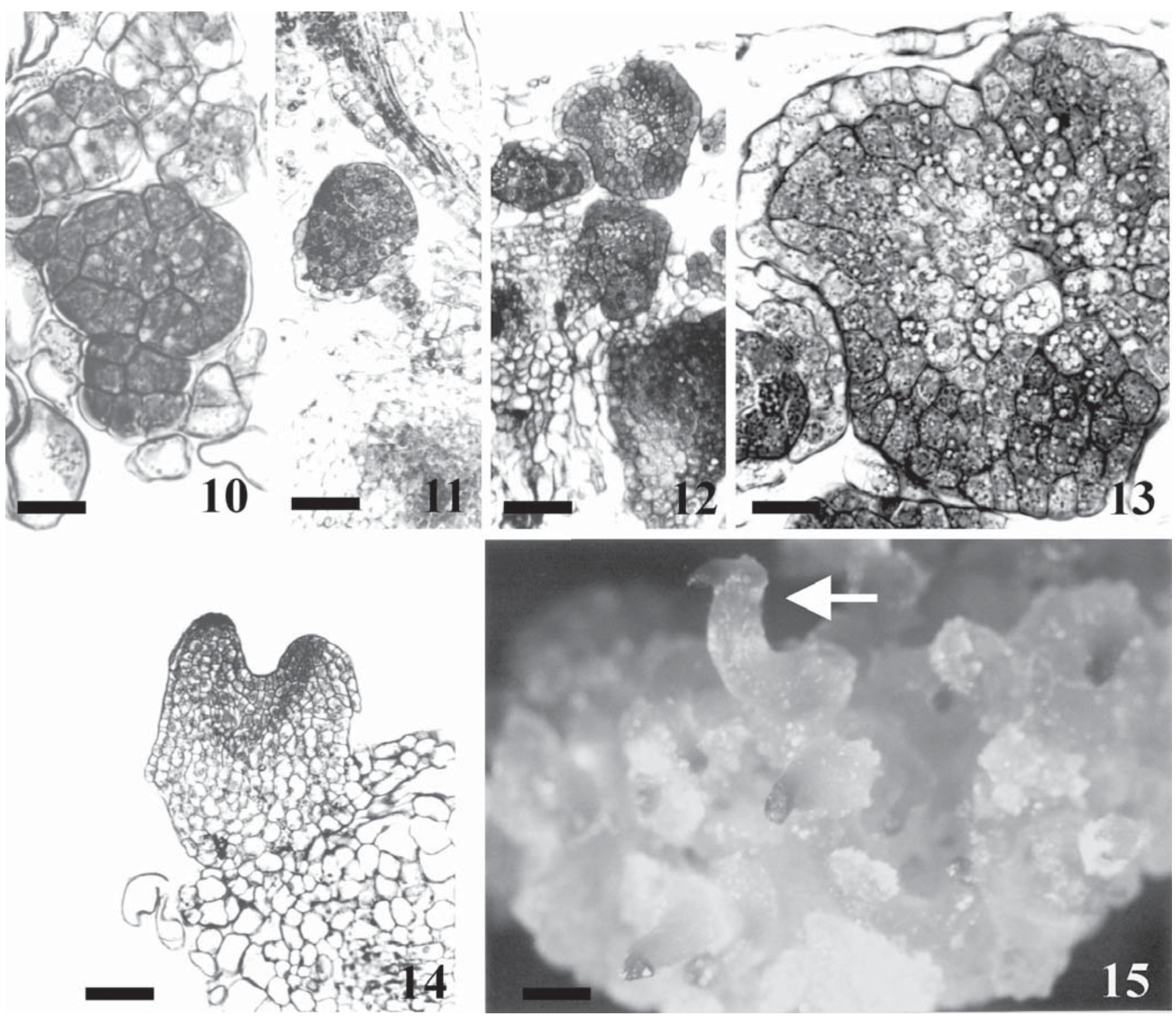

Figures 10-15. Development of somatic embryos from cotyledon explants of eggplant. 10. Globular embryo formed on a sixday-old explant. 11. Globular late shaped embryo after six days in culture. 12. Heart shaped embryo after eight days in culture. 13. Detail of heart shaped embryo showing starch grains. 14. Torpedo stage embryo lacking the root pole, after 30 days in culture. 15. Embryogenic callus after 30 days in culture. arrow $=$ embryo. Bars $=18 \mu \mathrm{m}(10) ; 139 \mu \mathrm{m}(11) ; 94.73 \mu \mathrm{m}(12) ; 11.25 \mu \mathrm{m}$ (13); $150 \mu \mathrm{m}(14) ; 1 \mathrm{~mm}(15)$. 


\section{Discussion}

The anatomical analysis conducted here has revealed the cellular origin and anatomical development of NAA induced somatic embryos from cotyledonar explants in eggplant. In this system, proembryos were observed as early as two days after culture initiation. Studies on somatic embryo development of other species reported significantly longer periods for embryo or embryogenic callus formation, most of them longer than ten days (Ozias-Akins \& Vasil 1982, van Hengel et al. 1998, Bespalhok Filho \& Hattori 1997, Hutchinson et al. 1996, Ho \& Vasil 1983, Sagare et al. 1995, Laparra et al. 1997, Guerra \& Handro 1998) and some of them reaching up to 40-60 days (Schwendiman et al. 1988, Thomas et al. 1972).

In the present work we demonstrated that somatic embryos could be derived either from perivascular cells or vascular tissues, through different processes. While perivascular cells originated somatic embryos directly, parenchymatous cells of the vascular bundle first gave rise to IMMs. A similar behavior was reported by Haccius (1978) who observed embryo formation both indirectly from proembryonic cell complexes and directly from single cells. PEMs can be considered as an equivalent of an embryogenic callus in accordance with the results of Ho \& Vasil (1983); Schwendiman et al. (1988) as well as Buffard-Morel et al. (1992) and thus a pathway to indirect embryogenesis.

In addition to originating PEMs, the IMMs apparently were able to follow two other pathways: a) redifferentiation to form new tracheary elements which gave rise to vascular bundles and $b$ ) formation of root primordia. The differences observed in the mechanisms of embryo formation as well as in the fate of the IMMs may reflect alterations on the amount of NAA available in the medium and/or be a result of its differential uptake and distribution in the cotyledonary tissues.

The initiation of root primordia after a certain period of culture is a recurrent event in somatic embryogenesis induction experiments, usually related to decreased levels of auxin (Matsuoka \& Hinata 1979, Ho \& Vasil 1983). Buffard-Morel et al. (1992) have proposed that the same growth regulator could induce roots and somatic embryos from coconut. However, direct evidence of the common origin of somatic embryos and adventitious roots has not been provided. In this work, both root primordia and PEMs were originated from the IMMs and showed structural similarities such as the presence of three different regions.
In both cases the proximal region relative to the vascular bundles is composed of parenchymatic cells while the middle region is characterized by having a meristematic activity, forming new cells in both proximal and distal directions. A similar pattern in the cambiumlike zone of nodular callus derived from perivascular cells, has been described by other authors (Ozias-Akins \& Vasil 1982, Ho \& Vasil 1983, Schwendiman et al. 1988, Buffard-Morel et al. 1992, Guerra \& Handro 1998). The distal region is formed by potentially detachable cells, either by being converted in somatic embryos or by being exfoliated in root caps. In both cases the cells of this region exhibited starch grains which were proposed to be somatic embryogenesis markers (Buffard-Morel et al. 1992) while in normal roots they are known to act as statholiths (Mauseth 1995). The presence of starch grains in root primordia has also been reported in several other somatic embryogenesis systems (Thomas et al. 1972, Street \& Withers 1974, Ozias-Akins \& Vasil 1982, Lu \& Vasil 1985, Schwendiman et al. 1988).

Although the great majority of embryos were able to originate whole plants upon transfer to MS0, monopolar torpedo embryos were also observed in 30day-old calluses (data not shown). Such embryos were also described for Helianthus smithii Heiser (Laparra et al. 1997), Cicer arietinum L. (Shri \& Davis 1992), Sorghum (Thomas et al. 1972, Vasil et al. 1985). Laparra (1997) and Thomas (1972) interpreted them as an aborted somatic embryo, probably due to the low levels of auxin, insufficient for the establishment of the root pole.

In conclusion, we described the specific features of origin and development of somatic embryos in eggplant, providing a fully characterized model for the study of gene regulation during embryo development. The analysis of the cytological nature of the origin of the meristematic cell clusters should rely upon additional morphological or molecular markers.

Acknowledgments -The authors thank L. Frade, M. Sabino, F. Barbosa and R.C.R.Gama for technical assistance and to Dr. M. Lima for critical reading of the manuscript. E. Tarré was an undergraduate student supported by $\mathrm{CNPq} / \mathrm{Pibic}$ and C. Magioli was a Ph.D fellow supported by CNPq.

\section{References}

BESPALHOK FILHO, C.J. \& HATTORI, K. 1997. Embryogenic callus formation and histological studies from Stevia rebaudiana (Bert.) Bertoni floret explants. Revista Brasileira de Fisiologia Vegetal 9:185-188. 
BUFFARD-MOREL, J., VERDEIL, J.L. \& PANNETIER, C. 1992. Embryogenèse somatique du cocotier (Cocos nucifera L.) à partir d'explants foliaires: études histologiques. Canadian Journal of Botany 70:735-741.

DODEMAN, V.L., DUCREUX, G. \& KREIS, M. 1997. Zygotic embryogenesis versus somatic embryogenesis. Journal of Experimental Botany 48:1493-1509.

FILLIPONE, E. \& LURQUIN, P.F. 1989. Stable transformation of eggplant (Solanum melongena L.) by cocultivation of tissues with Agrobacterium tumefaciens carrying a binary plasmid vector. Plant Cell Report 8:370-373.

GAHAN, B.P. 1984. Plant Histochemistry and Cytochemistry. Academic Press, London.

GLEDDIE, S., KELLER, W. \& SETTERFIELD, G. 1983. Somatic embryogenesis and plant regeneration from leaf explants and cell suspensions of Solanum melongena L. (eggplant). Canadian Journal Botany 61:656-666.

GUERRA, M.P. \& HANDRO, W. 1998. Somatic embryogenesis and plant regeneration in different organs of Euterpe edulis Mart. (Palmae): control and structural features. Journal of Plant Research 111:65-71.

HACCIUS, B. 1978. Question of unicellular origin of nonzygotic embryos in callus cultures. Phytomorphology 28:74-81.

HO, W.J. \& VASIL, I.K. 1983. Somatic embryogenesis in sugarcane (Saccharum officinarum L.) I. The morphology and physiology of callus formation and the ontogeny of somatic embryos. Protoplasma 118:169-180.

HUTCHINSON, M.J., KRISHNARAJ, S. \& SAXENA, P.K. 1996. Morphological and physiological changes during thidiazuron-induced somatic embryogenesis in geranium (Pelargonium x hortorum Bailey) hypocotyl cultures. International Journal of Plant Sciences 157:440-446.

LAPARRA, H., BRONNER, R. \& HAHNE, G. 1997. Histological analysis of somatic embryogenesis induced in leaf explants of Helianthus smithii Heiser. Protoplasma 196:1-11.

LU, C. \& VASIL, I.K. 1985. Histology of somatic embryogenesis in Panicum maximum (Guinea grass). American Journal of Botany 72:1908-1913.

MAGIOLI, C., ROCHA, A.P.M., TARRÉ, E., SANTIAGOFERNANDES, L.D., OLIVEIRA, D.E., KRUL, W.R. \& MANSUR, E. 2001. Effect of morphological factors, antibiotics and Agrobacterium co-cultivation in the efficiency of somatic embryogenesis of eggplant (Solanum melongena L.). Journal of Plant Biotechnology 3:19-25.

MATSUOKA, H. \& HINATA, K. 1979. NAA-induced organogenesis and embryogenesis in hypocotyl callus of Solanum melongena L. Journal of Experimental Botany 30:363-370.

MAUSETH, J.D. 1995. Botany - An introduction to plant biology. Saunders College Publishing, San Francisco.

MURASHIGE, R. \& SKOOG, F. 1962. A revised method for rapid growth and bioassays with tissue cultures. Plant Physiology 15:473-497.
NEWMAN, P.O., KRISHNARAJ, S. \& SAXENA, P.K. 1996. Regeneration of tomato (Lycopersicon esculentum Mill.): somatic embryogenesis from hypocotyl explants induced with 6-benzyladenine. International Journal of Plant Sciences 157:554-560.

OZIAS-AKINS, P. \& VASIL, K.I. 1982. Plant regeneration from cultured immature embryos and inflorescences of Triticum aestivum L. (wheat): evidence for somatic embryogenesis. Protoplasma 110:95-105.

RAO, P.V.L. \& SINGH, B. 1991. Plantlet regeneration from encapsulated somatic embryos of hybrid Solanum melongena L. Plant Cell Report 10:7-11.

SAGARE, A.P., SUHASINI, K., KRISHNAMURTHY, K.V. 1995. Histology of somatic embryo initiation and development in chickpea (Cicer arietinum L.). Plant Science 109:87-93.

SAITO, T. \& NISHIMURA, S. 1994. Improved culture conditions for somatic embryogenesis using an aseptic ventilative filter in eggplant (Solanum melongena L.). Plant Science 102:205-211.

SCHMIDT, E.D.L., JONG, J.A. \& DE VRIES, S.C. 1994. Signal molecules involved in plant embryogenesis. Plant Molecular Biology 26:1305-1313.

SCHWENDIMAN, J., PANNETIER, C. \& MICHAUXFERRIERE, N. 1988. Histology of somatic embryogenesis from leaf explants of the oil palm Elaeis guineensis. Annals of Botany 62:43-52.

SHRI, P.V. \& DAVIS, P.M. 1992. Zeatin-induced shoot regeneration from immature chickpea (Cicer arietinum L.) cotyledons. Plant Cell Tissue and Organ Culture 28:45-51.

STREET, H.E. \& WITHERS, L.A. 1974. The anatomy of embryogenesis in culture. In Tissue Culture and Plant Science. (H.E. Street, ed.). Academic Press, London. p.71-100.

STUART, D.A., STRICKLAND, S.G. \& WALKER, K.A. 1987. Bioreactor production of alfalfa somatic embryos. HortScience 22:800-803.

THOMAS, E., KONAR, N.R. \& STREET, E.H. 1972. The fine structure of the embryogenic callus of Ranuculus sceleratus L. Journal of Cell Science 2:95-109.

VAN HENGEL, A., GUZZO, F., VAN KAMMEN, A. \& DE VRIES, S.C. 1998. Expression pattern of the carrot EP3 endochitinase gene in suspension cultures and in developing seeds. Plant Physiology 117:43-53.

VASIL, V., LU, C.-Y. \& VASIL, I.K. 1985. Histology of somatic embryogenesis in cultured immature embryos of maize (Zea mays L.). Protoplasma 127:1-8.

YAMADA, T., NAKAGAWA, H. \& SINOTO, Y. 1967. Studies on the differentiation in cultured cells. I - Embryogenesis in three strains of Solanum callus. Botanical Magazine Tokyo 80:68-74.

ZIMMERMAN, L.J. 1993. Somatic embryogenesis: a model for early development in higher plants. The Plant Cell 5:1411-1423. 